\title{
Analisis Penggunaan FUNGSI terhadap Data Pekerjaan di Desa Karakan 06
}

\author{
Rizki Hanif Fansyah ${ }^{1 *}$, Edo Pras Setio ${ }^{2}$ \\ *e-mail : rizkihanif40@gmail.com \\ ${ }^{1}$ Program Studi S1 Informatika, Fakultas Ilmu Komputer \\ Universitas Amikom Yogyakarta \\ ${ }^{2}$ Program Studi S1 Informatika, Fakultas Ilmu Komputer \\ Universitas Amikom Yogyakarta
}

\begin{abstract}
The research objective of the Analysis of Use of FUNCTION on Job Data in Karakan Village was to publish the most important form of livelihood in Karakan village 06. The method used for this study was to use the FUNCTION method. the results derived from this study are that we can find out the percentage of the most work as livelihoods in Karakan village 06.
\end{abstract}

Keywords: function, job data

\begin{abstract}
ABSTRAK
Tujuan penelitian Analisis Penggunaan FUNGSI terhadap Data Pekerjaan di Desa Karakan yaitu bertujuan untuk mengetahui presentase perkerjaan yang paling banyak digunakan sebagai mata pencaharian di desa karakan 06. metode yang digunakan untuk penelitian ini adalah dengan menggunakan metode FUNGSI. hasil yang dicapai dari penelitian ini yaitu kita dapat mengetahui presentase pekerjaan yang paling banyak digunakan sebagai mata pencaharian di desa karakan 06.
\end{abstract}

Kata Kunci: fungsi, data pekerjaan

\section{PENDAHULUAN}

Pekerjaan yaitu sebuah roda yang menggerakan sebuah pembangunan dan jumlah tenaga kerja tersebut akan terus mengalami perubahan seiring dengan adanya perkembangan jaman dan sistem ekonomi yang ada setiap tahun nya akan berkembang begitu pesat,ekspor melemah akan tetapi impor terus berkembang, pada tahun 2017-2018 peningkatan impor untuk keprluan Indonesia sangat meningkat derastis seperti halnya impor garam, dalam hal ini kami bertujuan untuk mendata jenis pekerjaan yang ada di suatu daerah apakah daerah tersebuat terdapat penduduk yang belum mendapatkan pekerjaan atau belum mendapatka pekerjaan yang belum layak maka apa bila ada penduduk yang belum mendpatkan pekaerjaan maupun sudah ada pekerjaan tetatpi belum layak maka dari data tersebut kita dapat menyalurkan data tersebut ke pemerintah sekitar agar penduduk tersebuat mendapatkan pekerjaan yang layak atau di berikan pelatihan dan lapanagan pekerjaan yang nantinya juga bertujuan untuk meningkatkan perekonomian negara tersebut.

Pada jaman sekarang sebuah data pekerjaan disuatu daerah sangat dibutuhkan dengan tujuan untuk mendata 
atau mendapatkan suatu data pekerjaan penduduk sekitar, dari data tersebut kita dapat mendapatakan data berupa, apa saja jenis pekeerjaan di daerah tersebut, berapa presentase dari setiap pekerjaan, jenis pekerjaan yang paling banyak digunakaan sebagai mata pencaharian di daerah tersebut, dan berapakah jumlah pengangguran di daerah tersebut.

Pada penelitian atau pendataan pekerjaan disuatu daerah kami menggunakan sebuah metode fungsi surjektif. Disebuah desa Karakan 06 terdapat beberapa jenis pekerjaan yang paling banyak di gunakan unutk mata pencaharian yaitu adalah petani, ada juga yang bekerja sebagai kuli bangunan, guru, dan PNS dll. Dalam kasusu ini kami mengambil beberapa sampel data pekerjaan penduduk, diantaranya yaitu pak suharjo bekerja sebagai petani, Ngatimin bekerja sebagai Kuli, Mbah Kamto bekerja sebagai Petani, Ahmadi bekerja sebagai PNS, dan Annisa bekerja sebagai Guru.

\section{BAHAN DAN METODE}

\section{Jenis Penelitian}

Jenis penelitian yang digunakan disini yaitu menganalisis pengunaan fungsi terhadap Data Pekerjaan di desa Karakan 06. Fungsi adalah sebuah hubungan antara dua himpunan bilangan sama seperti pemetaan dari sebuah fungsi biasanya berfungsi sebagai sebuah pernyataan penghubung antara dua atau beberapa objek.

Fungsi surjektif yaitu fungsi yang setiap anggota domain nya mempunyai anggota kodomain atau daerah kawan.

\section{Target Penelitian}

Target penelitian nya yaitu Masyarakat yang terdapat di desa Karakan 06, dan pemerintah sekitar.

3. Metode Pengumpulan Data
Kami mengumpulkan beberapa sampel data pekerjaan penduduk di desa karakan 06, data yang diambil hanyalah data pekerjaan yang paling banyak digunakan sebagai mata pencaharaian.

\section{Sumber Data}

Sumber data yang kami dapatkan yaitu mendata langsung data pekerjaan di desa karakan 06, tetapi kami hanya mengambil beberapa data saja.

5. Pengolahan dan Analisis Data

Pengolahan dan analisis yang kami lakukan yaitu untuk pendataan jenis pekerjaan di desa tersebut dan mengetahui presentase perkerjaan yang paling banyak digunakan sebagai mata pencaharian di desa karakan 06.

6. Paradigma

Kami beranggapan bahwa ada kemungkinan pada desa karakan 06, pengumpulan data pekerjaan belum begitu bermanfaat untuk mengembangkan perekonomian sekitar, dan kemungkinan data tersebut tidak digunakan.

\section{HASIL DAN PEMBAHASAN}

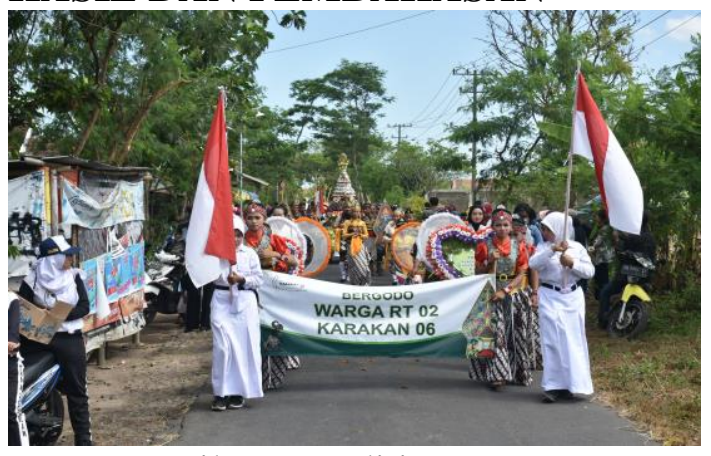

Hasil penelitian memuat ringkasan data dari penelitian tanpa mendiskusikan implikasinya, ringkasan dalam bentuk yang paling informatif dapat diringkas dalam bentuk tabel/grafik/gambar dan harus dijelaskan dalam teks.

Fungsi dalam istilah matematika adalah suatu pemetaan setiap anggota dari sebuah himpunan atau biasa disebut sebagai domain yaitu daerah asal, kepada anggota himpunan yang lain atau dinamakan sebagai kodomain atau 
disebut daerah kawan. Fungsi adalah sebuah pemetaan, sebuah anggota himpunan yang dipetakan dapat berupa, sebuah objek, bilagan, orang, dan kata, tetapi yang sering muncul dan sering dibahas adalah besaran matematika seperti bilangan rill. Terdapat beberapa jenis fungsi diantaranya yaitu, fungsi injektif atau one to one, fungsi surjrktif apabila setiap anggota domain nya mempunyai anggota kodomain atau daerah kawan, dan fungsi bijektif merupaka gabungan antara fungsi injektif dan surjektif. Menghitung nilai fungsi, nilai fungsi dapat dengan cara berupa table fungsi, dari table fungsi kita dapat memuat daerah asal atau domain dan bayangannya. Dalam kasus ini akan menggunakan metode Fungsi surjektif yaitu fungsi yang setiap anggota domain nya mempunyai anggota kodomain atau daerah kawan, dan apabila salah satu angota domain tidak memilik daerah kodomain maka itu bukanlah fungsi surjektif.

Disebuah desa Karakan 06 diambil beberapa sampel data pekerjaan penduduk, diantaranya yaitu pak suharjo bekerja sebagai petani, Ngatimin bekerja sebagai Kuli, Mbah Kamto bekerja sebagai Petani, Ahmadi bekerja sebagai PNS, dan Annisa bekerja sebagai Guru. Dari data pekerjaan tersebut kita akan menuliskan daerah asal atau domain, dan daerah kawan atau kodomain, dan daerah hasil fungsi f. serta kita akan mencari $\mathrm{f}$ (suharjo), f (Ngatimin), f (Mbah Kamto), f (Mbah Rois), f (Ahmadi), f (Annisa).

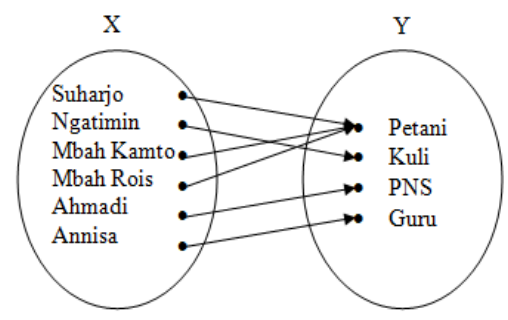

Penyelesaian:

1. Daerah asal (domain) fungsi $\mathrm{f}$ adalah himpunan $X=\{$ Suharjo,
Ngatimin, Mbah Kamto, Mbah

Rois, Ahmadi, Annisa).

Kodomain $\mathrm{f}$ adalah himpunan $\mathrm{Y}=$

\{Petani, Kuli, PNS, Guru\}.

Daerah hasil fungsi $f$ adalah

himpunan elemen-elemen dalam $\mathrm{Y}$ yang mempunyai kawan di $\mathrm{X}$, yaitu \{Petani, Kuli, PNS, Guru\}.

2. $\mathrm{f}($ Suharjo $)=$ Petani; $\mathrm{f}($ Ngatimin $)=$ Kuli; f=(Mbah Kamto $)=$ Petani; $\mathrm{f}($ Mbah Rois $)=$ Petani; $\mathrm{f}($ Ahmadi $)$ $=$ PNS; $\mathrm{f}($ Annisa $)=$ Guru.

3. $\mathrm{f}=\{($ Suharjo, Petani), (Ngatimin, Kuli), (Mbah Kamto, Petani), (Mbah Rois, Petani), (Ahmadi, PNS), (Annisa, Guru) $\}$ dari $\mathrm{A}=$ \{Suharjo, Ngatimin, Mbah Kamto, Mbah Rois, Ahmadi, Annisa $\}$ B = \{Petani, Kuli, PNS, Guru $\}$ merupakan fungsi pada karena semua anggota $B$ merupakan jelajah dari f.

Tabel 1. Data Pekerjaan

\begin{tabular}{|l|l|}
\hline Nama & Pekerjaan \\
\hline Suharjo & Petani \\
\hline Ngatimin & Kuli \\
\hline Mbah Kamto & Petani \\
\hline Mbah Rois & Petani \\
\hline Ahmadi & PNS \\
\hline Annisa & Guru \\
\hline
\end{tabular}

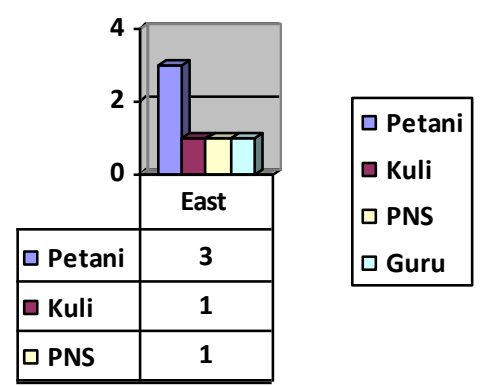

Gambar 1. Diagram Batang Data Pekerjaan 


\section{KESIMPULAN}

Dari penelitian tersebut kita dapat menyimpulkan.

1. Fungsi adalah sebuah pemetaan, sebuah anggota himpunan yang dipetakan dapat berupa, sebuah objek, bilagan, orang, dan kata, tetapi yang sering muncul dan sering dibahas adalah besaran matematika seperti bilangan rill.

2. Fungsi adalah suatu pemetaan setiap anggota dari sebuah himpunan atau biasa disebut sebagai domain yaitu daerah asal, kepada anggota himpunan yang lain atau dinamakan sebagai kodomain atau disebut daerah kawan.

3. Menghitung nilai fungsi, nilai fungsi dapat dengan cara berupa table fungsi, dari table fungsi kita dapat memuat daerah asal atau domain dan bayangannya.

4. Presentase yang kita dapatkan dari data pekerjaan di desa karakan 06 tersebut adalah data Petani lebih banyak digunkanan sebagai mata pencaharian oleh masyarakat desa karakan 06 dengan jumlah 3 orang, sedangkan data Kuli, data PNS, dan data Guru hanya berjumlah 1 orang.

5. Fungsi surjektif yaitu fungsi yang setiap anggota domain nya mempunyai anggota kodomain atau daerah kawan, dan apabila salah satu angota domain tidak memilik daerah kodomain maka itu bukanlah fungsi surjektif, dari data yang sudah dibuat pada daerah domain semuanya mempunyai daerah kawan atau kodomain.

\section{Ucapan Terima Kasih}

Pada kesempatan ini penulis menyampaikan rasa terima kasih yang sebesar-besarnya kepada:

1. Allah SWT atas segala rahmat serta karunia-Nya yang telah memberikan kemudahan, kekuatan bagi penulis dalam menyelesaikan paper ini.

2. Kepada kedua orang tua tercinta kami yang selama ini telah membantu penulis, dalam hal memfasilitasi berupa laptop, kendaraan, dan segala kebutuhan, dalam bentuk kasih sayang, perhatian, semangat, serta doa yang tidak ada henti-hentinya mendoakan kami demi kelancaran serta kesuksesan dalam menyelesaikan paper ini.

3. Kepada Bapak Ferry Wahyu Wibowo, S.Si.,M.Cs. selaku dosen pengajar mata kuliah Metematika Diskrit yang selalu memberikan materi matematika diskrit kepada penulis, sehingga paper ini dapat terselesaikan tepat waktu.

4. Segenap dosen dan seluruh staf akademik yang selalu membantu dalam memberikan fasilitas, ilmu, serta pendidikan pada penulis, sehingga dapat menunjang dalam penyelesaian paper ini.

5. Terimaksih untuk Food Court Universitas Amikom Yogyakarta yang sudah menyediakan fasilitas berupa tempat, sehingga penulis mendapatkan tempat untuk mengerjakan tugas tersebut dengan nyaman.

6. Kepada para pembaca yang sudah menyempatkan waktunya untuk membaca, dan memberikan kritik dan saran yang nantinya dapat menyempurnakan tulisan paper tersebut.

7. Teman-teman seperjuangan dari 17 Informatika 05, yang telah 
bersama sama berjuang melewati masa masa kuliah sewaktu mata kuliah matematika diskrit.

8. Serta masih banyak lagi pihakpihak yang sangat berpengaruh dalam proses penyelesaian paper ini yang tidak bisa disebutkan satupersatu Semoga Allah SWT senantiasa membalas semua kebaikan yang telah diberikan. Semoga papaer ini dapat bermanfaat bagi penulis dan umumnya kepada para seluruh pembaca.

\section{DAFTAR PUSTAKA}

\section{Buku:}

Siang, Jong Jek. (2002). Matematika Diskrit dan Aplikasinya pada Ilmu Komputer. Yogyakarta:ANDI.

\section{Internet:}

Fungsi dan Relasi Matematika (Online), (http://www.magistermatematika.com/20 17/03/relasi-fungsi-pada-bab-ini-akandibahas.html?m=1), diakses 30 Oktober 2018

Jadijuara.com. (2017). Definisi, sifat dan jenis contoh soal fungsi. (Online), (http://jadijuara.com/contoh-soalfungsi/), diakses 02 November 2018

Wilson, D. (2017). Summary of Citing Internet Sites. NETTRAIN Discussion List, (Online), (http://www.materipendidikan.com/2017/ 10/contoh-soal-penerapan-relasi-danfungsi.html?m=1), diakses 30 Oktober 2018 